\title{
KKN-PPM (OH-BISA) OLAHAN BUAH PISANG "MANURUN" BERNILAI EKONOMI DAN BERBASIS TEKNOLOGI ADAFTIF LAHAN RAWA DI DESA MADUREJO KECAMATAN SAMBUNG MAKMUR KABUPATEN BANJAR
}

\author{
Nurul Huda ${ }^{1 *}$, Akhmad Yusuf $^{2}$ \\ ${ }^{1 *}$ Program Studi Matematika, Universitas Lambung Mangkurat \\ 2Program Studi Matematika, Universitas Lambung Mangkurat \\ Corresponding author: \\ E-mail : huda.oke@gmail.com
}

Diterima 30 April 2018, Disetujui 5 Mei 2018

\begin{abstract}
ABSTRAK
Desa Madurejo merupakan salah satu desa yang berada di Kecamatan Sambung Makmur Kabupaten Banjar Provinsi Kalimantan Selatan. Tanah Banjar yang sebagian berupa rawa-rawa yang subur dan lahan perkebunan yang luas menjadikan Kabupaten Banjar terkenal sebagai penghasil pisang terbesar terutama pisang "Manurun" di Kalimantan Selatan. Panen buah pisang tidak mengenal musim. Namun ketika masa panen besar, produksi buah pisang sangat melimpah. Permasalahan yang timbul dari kondisi maraknya kebun buah pisang di Sambung Makmur Kab. Banjar adalah kesulitan dalam memasarkan produk buah pisang. Buah pisang setelah panen tidak dapat bertahan lama. Banyaknya pesaing menaikkan resiko buah pisang menjadi busuk ketika buah segar tersebut tidak habis terjual. Sebuah solusi menggunakan teknologi tepat guna diperlukan untuk mengolah buah pisang segar tersebut menjadi suatu produk yang relatif bertahan lama, sehingga kerugian akibat tidak habis terjualnya buah pisang segar dapat dieliminasi. Hal inilah yang menjadi dasar tercetusnya hibah pengabdian dengan tema "KKN-PPM (OH-BISA) Olahan Buah Pisang "Manurun" Bernilai Ekonomi dan Berbasis Teknologi Adaptif Lahan Rawa di Desa Madurejo Kecamatan Sambung Makmur Kabupaten Banjar". Tujuan umum dari pengolahan buah pisang segar ini,diharapkan program ini tidak hanya akan menambah nilai (added value) dari buah pisang itu sendiri, namun juga meningkatkan taraf ekonomi masyarakat sekitar melalui potensi penciptaan lapangan kerja berbasis olahan buah pisang pasca panen. Adapun target capaian program ini adalah (1) Produksi olahan buah pisang(keripik, Sale, Selai dan dodol) dengan teknologi tepat guna, (2) Peningkatan pendapatan masyarakat sebesar $50 \%$ dari pendapatan sebelumnya, (3) Pembuatan manajemen pemasaran produk yang efektif dan inovatif (4) Peningkatan swadana dan swadaya masyarakat, serta mengajak mitra untuk meningkatkan perhatian terhadap masyarakat sekitar, khususnya di bidang peningkatan taraf ekonomi.(5) Peningkatan Soft Skill Mahasiswa
\end{abstract}

Kata kunci: Buah Pisang, Olahan, Selai, Dodol, Sale, Keripik.

\section{ABSTRACT}

Madurejo village is one of the villages located in Sambung Makmur Sub-district, Banjar District, South Kalimantan Province. Banjar land, partly in the form of fertile swamps and extensive plantation land makes Banjar Regency known as the largest banana producer, especially the "Manurun" banana in South Kalimantan. Harvest of bananas does not recognize the season. But when the harvest period is large, fruit banana production is very abundant. Problems arising from the widespread conditions of banana gardens in Sambung Makmur Kab. Banjar is a difficulty in marketing banana products. Bananas after harvest can not last long. The number of competitors raise the risk of bananas to rot when the fresh fruit is not sold out. A solution using appropriate technology is needed to process the fresh banana into a relatively long-lasting product, so the losses due to the unsold sell of fresh bananas can be eliminated. This is the basis for the eradication of a devotional grant with the theme "KKN-PPM (OH-BISA)" Banana Fruit Processing "Worth and Economy Based Adaptive Technology Swamp Land in Madurejo Village Sambung Makmur Sub-district, Banjar District". The general objective of this fresh banana fruit processing is expected to not only increase the added value of the banana itself, but also improve the economic level of the surrounding community through the potential for job creation based on post-harvest bananas. The target achievement of this program is (1) Production of processed bananas (chips, Sale, Jam and dodol) with appropriate technology, (2) Increase community income by $50 \%$ from previous revenues, (3) Making effective and effective product marketing 
management innovative (4) Increasing self-financing and self-help community, and invite partners to increase the attention to surrounding communities, especially in the field of increasing the level of economy. (5) Student Soft Skill Enhancement.

Keywords: Banana Fruit, Processed, Jam, Dodol, Sale, Chips.

\section{PENDAHULUAN}

Desa Madurejo merupakan salah salah satu desa yang terletak di Kecamatan Sambung Makmur Kabupaten Banjar Provinsi Kalimantan Selatan yang berjarak sekitar $12 \mathrm{~km}$ dari pusat kecamatan Sambung Makmur, dengan jumlah penduduk sebanyak 3161 jiwa.Tanah Banjar yang subur dan lahan yang luas menjadikan daerah ini menjadi sentra produksi buah pisang di Kalimantan Selatan (Iqbal, 2015). Arti penting prasasti-prasasti yang ditemukan di nusantara (Indonesia) adalah sebagai media untuk penelitian astronomi dan karena Tak ada musim atau waktu khusus untuk panen membuat harga buah pisang relatif stabil dari waktu ke waktu. Permasalahan timbul pada masa panen besar dimana produksi buah pisang sangat melimpah. Buah pisang segar biasanya hanya bertahan sekitar 10 hari. Tingginya persaingan penjualan buah pisang menjadikan buah pisang segar rentan busuk apabila tidak habis terjual.

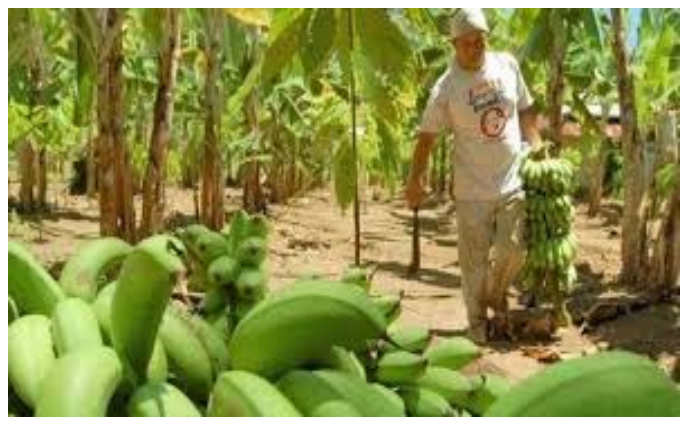

Gambar 1. Kebun Pisang di Banjar

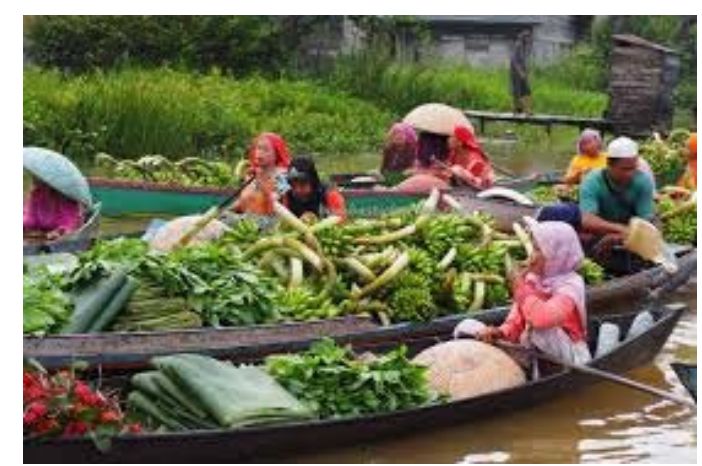

Gambar 2. Pasar Terapung yang Menjual Pisang

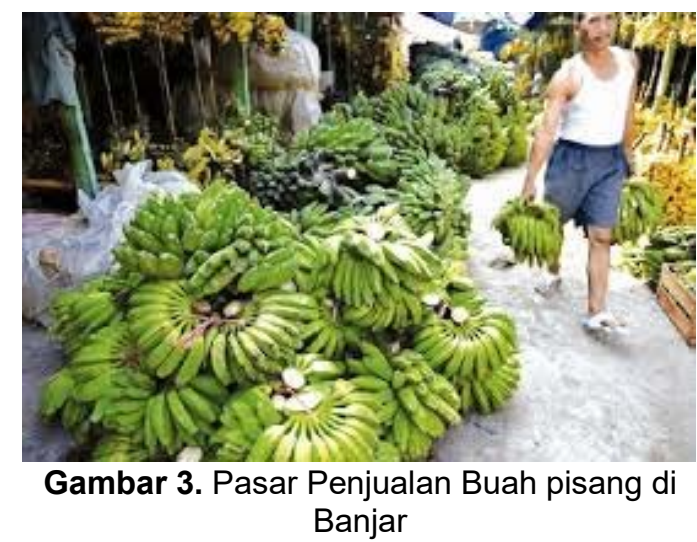

Hal inilah yang menjadi dasar terselenggaranya program hibah pengabdian dengan tema "KKNPPM (OH-BISA) Olahan Buah Pisang "Manurun" Bernilai Ekonomi dan Berbasis Teknologi Adaptif Lahan Rawa di Desa Madurejo Kecamatan Sambung Makmur Kabupaten Banjar". Diharapkan program ini tidak hanya akan menambah nilai (added value) dari buah pisang itu sendiri, namun juga meningkatkan taraf ekonomi masyarakat sekitar melalui potensi penciptaan lapangan kerja berbasis olahan buah pisang pasca panen.

\section{$\underline{\text { Target dan Luaran }}$}

Target dan Luaran yang ingin dicapai dari kegiatan Program KKN-PPM (OH-BISA) Olahan Buah Pisang "Manurun" Bernilai Ekonomi dan Berbasis Teknologi Adaptif Lahan Rawa di Desa Madurejo Kecamatan Sambung Makmur Kabupaten Banjar ini adalah :

1. Memberdayakan masyarakat bersama Mahasiswa untuk memproduksi olahan buah pisang (Keripik, Sale, Dodol, dan Selai) dengan teknologi tepat guna

2. Peningkatan pendapatan masyarakat sebesar $50 \%$ dari pendapatan sebelumnya,

3. Pembuatan manajemen pemasaran produk yang efektif dan inovatif

4. Peningkatan swadana dan swadaya masyarakat, serta mengajak mitra untuk meningkatkan perhatian terhadap masyarakat sekitar, khususnya di bidang peningkatan taraf ekonomi.

5. Melatih Soft Skill Mahasiswa peserta KKN-PPM 


\section{METODE PELAKSANAAN}

A. Persiapan dan Pembekalan

a. Mekanisme pelaksanaan kegiatan KKN-PPM. Pelaksanaan Kegiatan KKN-PPM dilakukan melalui mekanisme sebagai berikut:

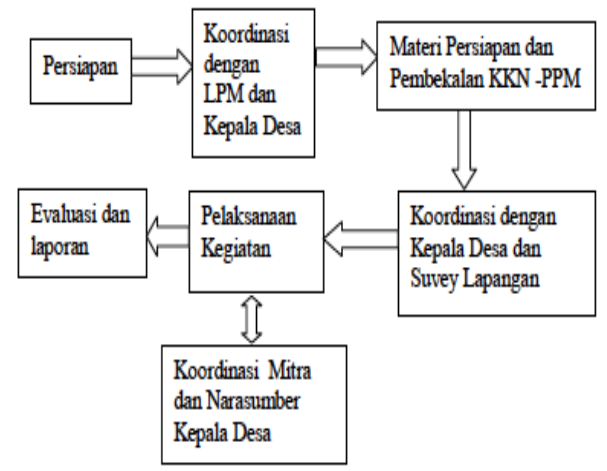

Gambar 4. Mekanisme Pelaksanaan Kegiatan KKN-PPM

b. Materi persiapan dan pembekalan yang perlu diberikan kepada mahasiswa yaitu:

1. Pemberdayaan masyarakat dalam pengolahan buah pisang segar

2. Pembuatan olahan buah pisang menjadi selai, dodol, dan sale dan keripik buah pisang

3. Model pemasaran buah pisang menggunakan online shop

4. Pemberdayaan masyarakat dalam peningkatan ekonomi

5. Pembekalan etika dengan masyarakat

B. Pelaksanaan

a. Langkah-langkah yang akan dilaksanakan untuk mencapai hasil yang diharapkan dari tema KKN-PPM yang diajukan, yaitu:

Tabel 1. Langkah Pelaksanaan

\begin{tabular}{|l|l|}
\hline No & Kegiatan \\
\hline 1 & Koordinasi dengan mitra \\
\hline 2 & $\begin{array}{l}\text { Sosialisasi program KKN PPM kepada } \\
\text { masyarakat }\end{array}$ \\
\hline 3 & $\begin{array}{l}\text { Pembekalan masyarakat olahan buah } \\
\text { pisang menjadi selai, dodol, dan sale buah } \\
\text { pisang }\end{array}$ \\
\hline 4 & $\begin{array}{l}\text { Pembekalan masyarakat mengenai } \\
\text { manajemen pemasaran menggunakan } \\
\text { online shopping }\end{array}$ \\
\hline 5 & $\begin{array}{l}\text { Pembekalan masyarakat mengenai ijin } \\
\text { usaha rumah tangga }\end{array}$ \\
\hline
\end{tabular}

b. Metode yang digunakan dalam melakukan pemberdayaan kelompok sasaran, yaitu:

Tabel 2. Metode Pelaksanaan

\begin{tabular}{|c|c|c|}
\hline No & Kegiatan & $\begin{array}{l}\text { Metode yang } \\
\text { digunakan }\end{array}$ \\
\hline 1 & $\begin{array}{l}\text { Koordinasi dengan } \\
\text { mitra }\end{array}$ & Koordinasi \\
\hline 2 & $\begin{array}{lr}\text { Sosialisasi } & \text { program } \\
\text { KKN PPM } & \text { kepada } \\
\text { masyarakat } & \end{array}$ & $\begin{array}{l}\text { Sosialisasi, } \\
\text { diskusi }\end{array}$ \\
\hline 3 & $\begin{array}{l}\text { Pembekalan } \\
\text { masyarakat olahan } \\
\text { buah pisang menjadi } \\
\text { keripik, sale, dodol } \\
\text { dan selai }\end{array}$ & $\begin{array}{l}\text { Pelatihan dan } \\
\text { diskusi }\end{array}$ \\
\hline 4 & $\begin{array}{l}\text { Pembekalan } \\
\text { masyarakat mengenai } \\
\text { pengemasan dan } \\
\text { manajemen } \\
\text { pemasaran } \\
\text { menggunakan online } \\
\text { shopping }\end{array}$ & $\begin{array}{l}\text { Pelatihan dan } \\
\text { diskusi }\end{array}$ \\
\hline 5 & $\begin{array}{l}\text { Pembekalan } \\
\text { masyarakat mengenai } \\
\text { ijin usaha rumah } \\
\text { tangga }\end{array}$ & $\begin{array}{l}\text { Sosialisasi, } \\
\text { pendampingan } \\
\text { pengurusan } \\
\text { PIRT }\end{array}$ \\
\hline
\end{tabular}

c. Kegiatan yang dilaksanakan selama 30 hari adalah:

Tabel 3. Kegiatan selama 30 Hari

\begin{tabular}{|l|l|l|}
\hline No & Nama Program & Metode \\
\hline 1. & $\begin{array}{l}\text { Sosialisasi/ Penyuluhan } \\
\text { mengenai bagaimana cara } \\
\text { pengolahan aneka buah } \\
\text { pisang }\end{array}$ & $\begin{array}{l}\text { Tatap muka, } \\
\text { demo }\end{array}$ \\
\hline 2. & $\begin{array}{l}\text { Praktik pembuatan keripik } \\
\text { pisang }\end{array}$ & $\begin{array}{l}\text { Tatap muka, } \\
\text { praktik }\end{array}$ \\
\hline 3. & $\begin{array}{l}\text { Praktik pembuatan sale } \\
\text { pisang }\end{array}$ & $\begin{array}{l}\text { Tatap muka, } \\
\text { praktik }\end{array}$ \\
\hline 4. & $\begin{array}{l}\text { Praktik pengolahan selai } \\
\text { pisang }\end{array}$ & $\begin{array}{l}\text { Tatap muka, } \\
\text { praktik }\end{array}$ \\
\hline 5. & $\begin{array}{l}\text { Praktik pengolahan dodol } \\
\text { pisang }\end{array}$ & $\begin{array}{l}\text { Tatap muka, } \\
\text { praktik }\end{array}$ \\
\hline 6. & $\begin{array}{l}\text { Perbaikan } \\
\text { MCK/WC }\end{array}$ & $\begin{array}{l}\text { Pembersihan, } \\
\text { Pengetikan } \\
\text { dan } \\
\text { Pembelian }\end{array}$ \\
\hline
\end{tabular}




\begin{tabular}{|c|c|c|}
\hline 7. & $\begin{array}{l}\text { Pemberian Pelajaran } \\
\text { Tambahan Bahasa Inggris }\end{array}$ & $\begin{array}{l}\text { Tatap muka, } \\
\text { peraga }\end{array}$ \\
\hline 8. & Menggambar & Lomba \\
\hline 9. & $\begin{array}{l}\text { Rangking } 1 \text {-Cerdas } \\
\text { Cermat }\end{array}$ & Lomba \\
\hline 10. & Tahlilan Warga Setempat & $\begin{array}{l}\text { Mengikuti } \\
\text { acara } \\
\text { masyarakat }\end{array}$ \\
\hline 11. & Maulid Habsyi & $\begin{array}{l}\text { Mengikuti } \\
\text { acara } \\
\text { masyarakat }\end{array}$ \\
\hline 12. & Solawat Nariyah & $\begin{array}{l}\text { Mengikuti } \\
\text { acara } \\
\text { masyarakat }\end{array}$ \\
\hline 13. & $\begin{array}{l}\text { Pembuatan } \\
\text { Sampah }\end{array}$ & $\begin{array}{l}\text { Praktek } \\
\text { langsung }\end{array}$ \\
\hline 14. & $\begin{array}{l}\text { Membersihkan } \quad \text { Mesjid } \\
\text { Nurul Huda }\end{array}$ & $\begin{array}{l}\text { Praktek } \\
\text { langsung }\end{array}$ \\
\hline 15. & $\begin{array}{l}\text { Membersihkan WC Umum } \\
\text { dan Tempat Wudhu }\end{array}$ & $\begin{array}{l}\text { Praktek } \\
\text { langsung }\end{array}$ \\
\hline 16. & $\begin{array}{ll}\text { Pemotongan } & \text { rumput } \\
\text { lapangan depan } & \text { Kantor } \\
\text { Desa } & \end{array}$ & $\begin{array}{l}\text { Praktek } \\
\text { langsung }\end{array}$ \\
\hline 17. & $\begin{array}{l}\text { Melengkapi sarana } \\
\text { pendidikan SD/MI } \\
\text { (Keterampilan dari stick } \\
\text { eskrim dan pemberian } \\
\text { poster presiden, wakil } \\
\text { presiden dan garuda } \\
\text { pancasila) }\end{array}$ & $\begin{array}{l}\text { Pembuatan } \\
\text { kerajinan dan } \\
\text { pembelian }\end{array}$ \\
\hline 18. & $\begin{array}{l}\text { Perbaikan gizi anak } \\
\text { sekolah (Pembagian bubur } \\
\text { kacang hijau) }\end{array}$ & Tatap muka \\
\hline 19. & $\begin{array}{l}\text { Pemeriksaan golongan } \\
\text { darah }\end{array}$ & $\begin{array}{l}\text { Tatap muka \& } \\
\text { Praktik }\end{array}$ \\
\hline 20. & $\begin{array}{l}\text { Perbaikan gizi masyarakat } \\
\text { (Pembagian bubur kacang } \\
\text { hijau) "JUMAHAT" Jumat } \\
\text { Madurejo Sehat }\end{array}$ & Tatap muka \\
\hline 21. & $\begin{array}{l}\text { Pemeriksaan tekanan } \\
\text { darah }\end{array}$ & $\begin{array}{l}\text { Tatap muka \& } \\
\text { Praktik }\end{array}$ \\
\hline 22. & $\begin{array}{lr}\text { Penyuluhan } & \text { di sekolah } \\
\text { (Penyuluhan } & \text { kebersihan } \\
\text { udara dan } & \text { pembagian } \\
\text { masker) } & \\
\end{array}$ & Tatap muka \\
\hline 23. & $\begin{array}{l}\text { Penyuluhan di sekolah } \\
\text { (Penyuluhan sikat gigi) }\end{array}$ & $\begin{array}{l}\text { Tatap muka \& } \\
\text { Praktik }\end{array}$ \\
\hline 24. & $\begin{array}{l}\text { Penyuluhan di sekolah } \\
\text { (Penyuluhan cuci tangan) }\end{array}$ & $\begin{array}{l}\text { Tatap muka \& } \\
\text { Praktik }\end{array}$ \\
\hline
\end{tabular}

\begin{tabular}{|c|c|c|}
\hline 25. & $\begin{array}{l}\text { Perbaikan gizi anak } \\
\text { sekolah } \\
\text { (Pembagian susu) }\end{array}$ & Langsung \\
\hline 26. & $\begin{array}{l}\text { Pemberian pelajaran } \\
\text { tambahan Matematika }\end{array}$ & $\begin{array}{l}\text { Tatap muka, } \\
\text { alat peraga, } \\
\text { game }\end{array}$ \\
\hline 27. & Sosialisasi Internet Sehat & Tatap muka \\
\hline 28. & $\begin{array}{l}\text { Acara Puncak Peringatan } \\
\text { Hari Anak Nasional } \\
\text { (Pembagian hadiah } \\
\text { Perlombaan) }\end{array}$ & $\begin{array}{l}\text { Seminar, } \\
\text { siaran, } \\
\text { hiburan }\end{array}$ \\
\hline 29. & $\begin{array}{l}\text { Penyerahan } \begin{array}{r}\text { Kenang- } \\
\text { Kenangan untuk SDN } \\
\text { Madurejo 2 }\end{array} \\
\end{array}$ & Langsung \\
\hline 30. & $\begin{array}{l}\text { Pengemasan } \\
\text { pemasaran }\end{array}$ & $\begin{array}{l}\text { Tatap muka, } \\
\text { praktik }\end{array}$ \\
\hline
\end{tabular}

d. Daftar Nama Mahasiswa Peserta KKN-PPM Desa Madurejo, Kec.Sambung Makmur, Kab. Banjar

Tim: Nurul Huda, S.Si., M.Si. \& Akhmad Yusuf, S.Si., M.Kom

\begin{tabular}{|c|c|c|c|}
\hline No & Nama & NIM & Prodi \\
\hline 1 & $\begin{array}{ll}\text { Tisna } & \text { Faisal } \\
\text { A } & \end{array}$ & J1A114058 & Matematika \\
\hline 2 & $\begin{array}{l}\text { Septa Nadia } \\
\text { Putri }\end{array}$ & J1A114033 & Matematika \\
\hline 3 & Sandanaria & J1A114032 & Matematika \\
\hline 4 & Fahrurrazi & J1A114061 & Matematika \\
\hline 5 & $\begin{array}{l}\text { Farohatin } \\
\text { Na'imah }\end{array}$ & J1A114009 & Matematika \\
\hline 6 & Rasinah & J1A114029 & Matematika \\
\hline 7 & $\begin{array}{l}\text { Annisa Rizki } \\
\text { Hafizah }\end{array}$ & J1A114001 & Matematika \\
\hline 8 & Winda Aulia & J1A114059 & Matematika \\
\hline 9 & Fiqriani Noor & J1A114043 & Matematika \\
\hline 10 & $\begin{array}{l}\text { Nugroho Arif } \\
\text { W. }\end{array}$ & J1A114051 & Matematika \\
\hline 11 & $\begin{array}{l}\text { Rizka Aulia } \\
\text { Norsafitri }\end{array}$ & J1E114032 & Farmasi \\
\hline 12 & $\begin{array}{l}\text { Siti } \\
\text { Istitha'atur R. }\end{array}$ & J1E114037 & Farmasi \\
\hline 13 & $\begin{array}{l}\text { Rifki Izdihar } \\
\text { O. }\end{array}$ & J1F114060 & $\begin{array}{l}\text { IImu } \\
\text { Komputer }\end{array}$ \\
\hline 14 & Felita Aulia & J1F114211 & $\begin{array}{l}\text { IImuKompu } \\
\text { ter }\end{array}$ \\
\hline 15 & Fitriani & J1A114012 & Matematika \\
\hline 16 & $\begin{array}{l}\text { Ratih } \\
\text { Wulandari }\end{array}$ & J1B114029 & Kimia \\
\hline 17 & $\begin{array}{l}\text { Raifa Azizia } \\
\text { Mustaqima }\end{array}$ & J1C114026 & Biologi \\
\hline 18 & Nani Aridah & J1C114025 & Biologi \\
\hline
\end{tabular}




\begin{tabular}{|c|l|l|l|}
\hline 19 & $\begin{array}{l}\text { Dyah Retno } \\
\text { W. }\end{array}$ & J1E114058 & Farmasi \\
\hline 20 & $\begin{array}{l}\text { Wildasari } \\
\text { Safitri }\end{array}$ & J1E114220 & Farmasi \\
\hline
\end{tabular}

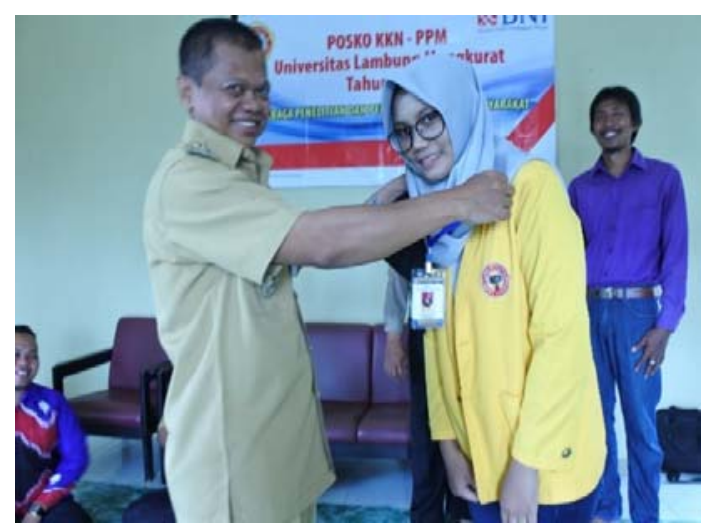

Gambar 5. Penyematan Peserta KKN

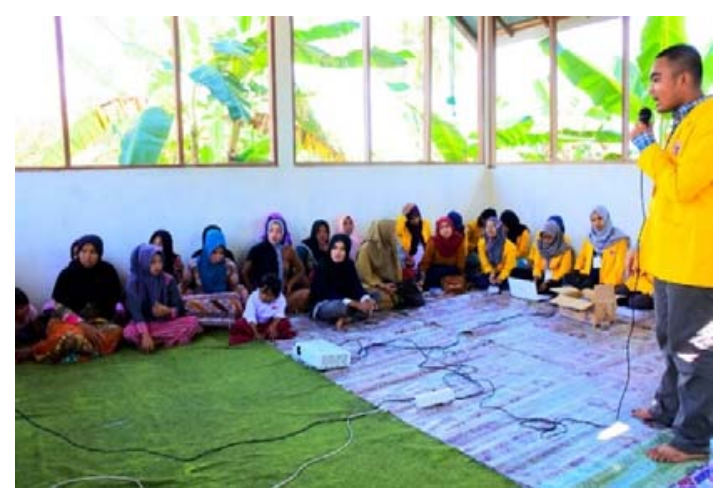

Gambar 6. Sosialisasi Program KKN

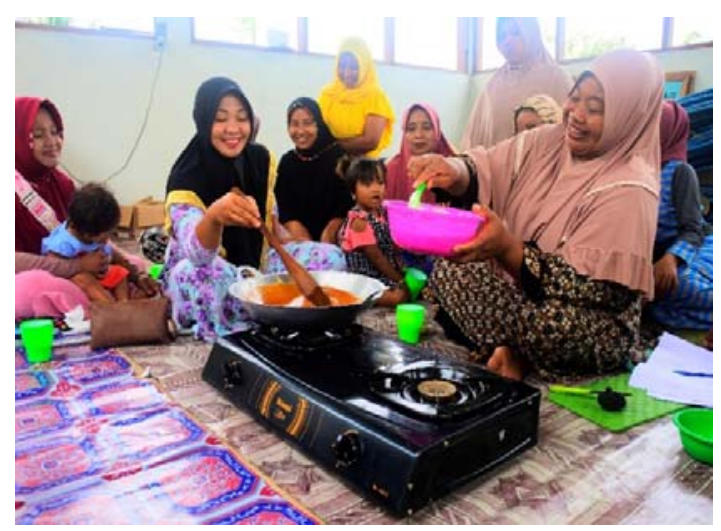

Gambar 7.Praktik Pengolahan Pisang

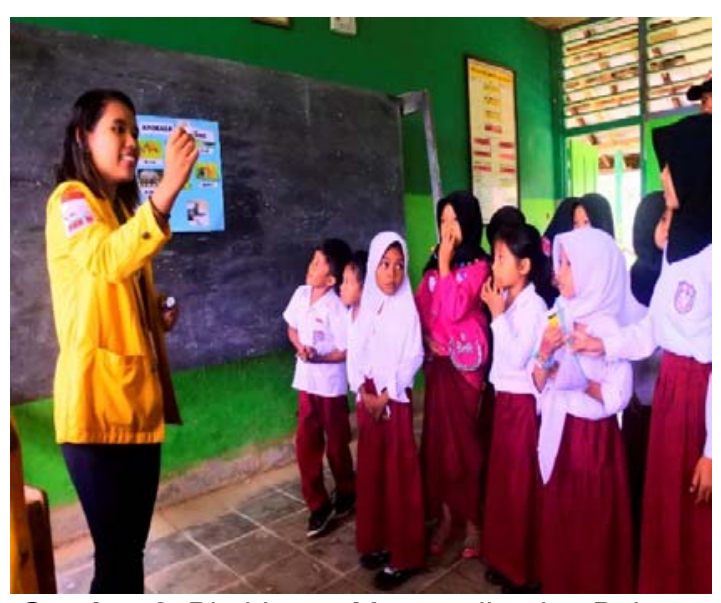

Gambar 8. Bimbingan Matematika dan Bahasa Inggris

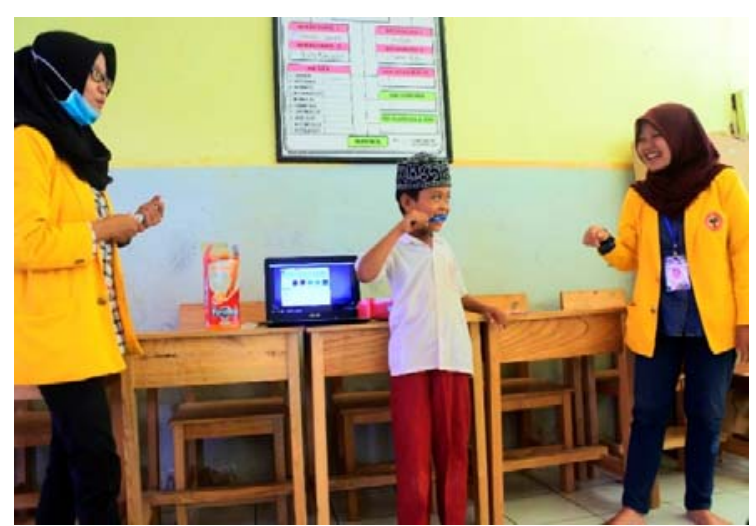

Gambar 9. Sosialisasi Gosok Gigi Yang Benar

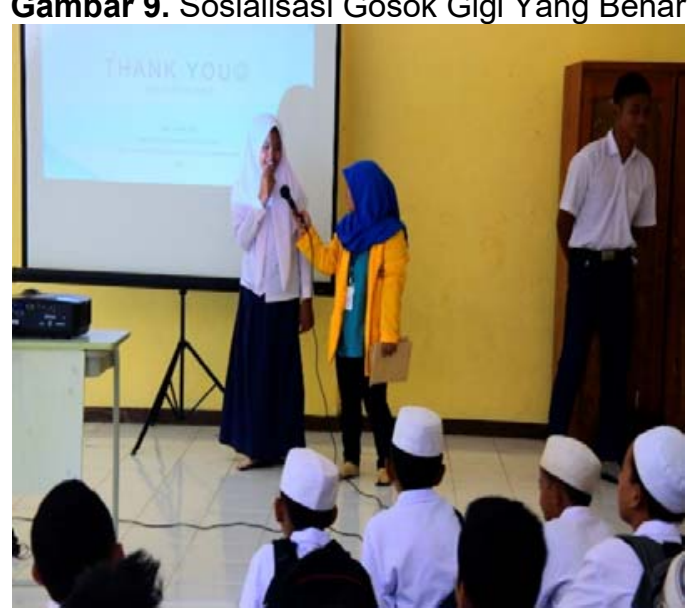

Gambar 10. Sosialisasi Internet Sehat 


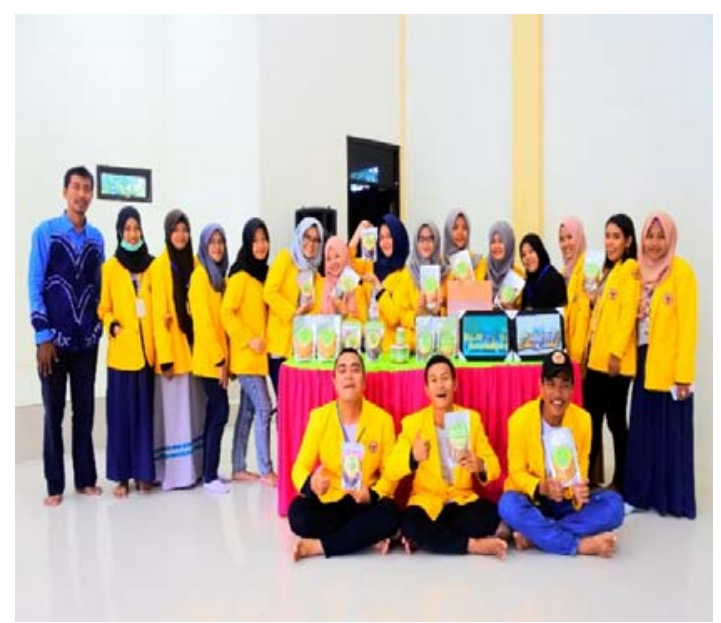

Gambar 11.Lokakarya KKN

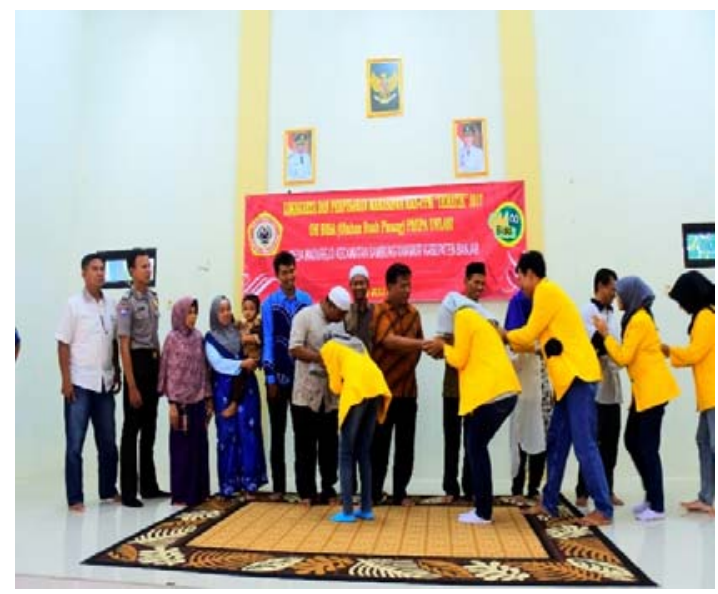

Gambar 12. Pamitan Mahasiswa KKN

\section{Kelayakan Perguruan Tinggi}

Universitas Lambung Mangkurat telah berkomitmen untuk melaksanakan KKN-PPM di sejumlah desa dalam wilayah Kalimantan Selatan. Kuliah kerja nyata Universitas Lambung Mangkurat telah direncanakan, dilaksanakan dan dievaluasi secara berkesinambungan dalam rangka mewujudkan visi Universitas menjadi Universitas yang maju dan berdedikasi dengan masyarakat luas dalam rangka memampukan dan memandirikan masyarakat dalam membangun diri dan lingkungannya. Pada tahun sebelumnya, Fakultas MIPA UNLAM sendiri telah berhasil mendapatkan beberapa judul hibah KKN-PPM yaitu pemberdayaan masyarakat melalui diversifikasi olahan rimpang obat herbal, pengolahan sampah rumah tangga menjadi pupuk dan kerajinan tangan khas daerah, dan Olahan Buah Naga (Olga) Berbasis Teknologi Tepat Guna Sebagai Added Value Ekonomi Masyarakat Desa Sungai Riam, Kecamatan Pelaihari-Tanah Laut
Dengan adanya kegiatan KKN-PPM masyarakat menerima transfer pengetahuan teknologi tepat guna, sehingga masyarakat terlibat aktif dalam peningkatan taraf hidup dan dapat mandiri secara ekonomi. Disamping itu KKN-PPM ini juga diharapkan dapat mengatasi permasalahan daya tahan buah pisang pasca panen melalui metode diversifikasi produk berbasis teknologi tepat guna.Hal ini diharapkan mampu menginisiasi masyarakat untuk melihat potensi alam yang bisa dikembangkan untuk sumber pendapatan.Mitra yang terkait juga diharapkan terlibat aktif dalam peningkatan taraf hidup masyarakat sekitarnya.

\section{HASIL DAN PEMBAHASAN}

Hasil dan Luaran Yang Dicapai

Hasil Luaran Yang Sudah Dicapai dari kegiatan KKN-PPM ini adalah:

(1) Produksi olahan buah pisang yaitu: Keripik, Sale, Dodol dan Selai

(2) Kemasan Produk yang bagus layak jual di minimarket

(3) ijin PIRT dari Dinas Kesehatan

(4) Alat Produksi Keripk, Sale, dodol dan Selai,

(5) Publikasi di Media Massa / koran

(6) Publikasi di Media Elektronik/ Televisi

(7) Terjalin kerjasama dengan toko oleh-oleh.

(8) Peningkatan Soft Skill Mahasiswa

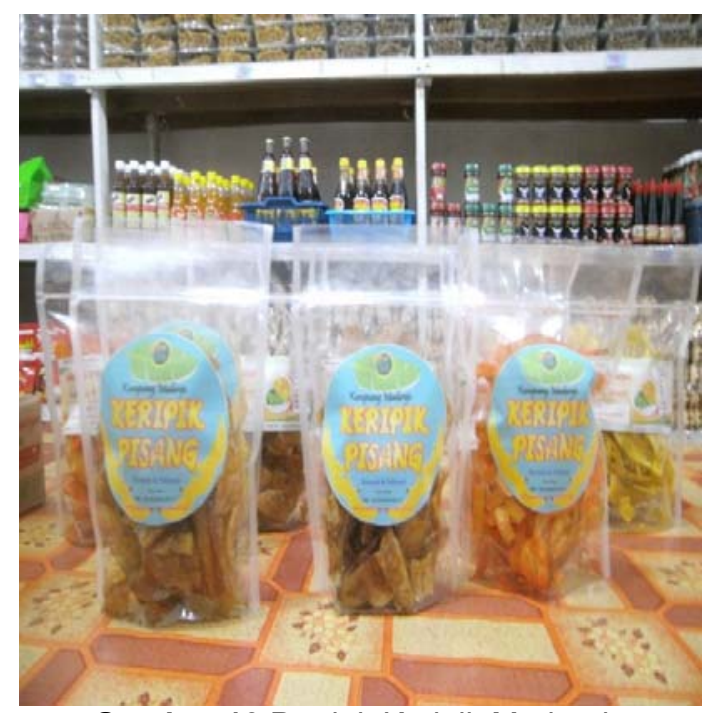

Gambar 13.Produk Keripik Madurejo 


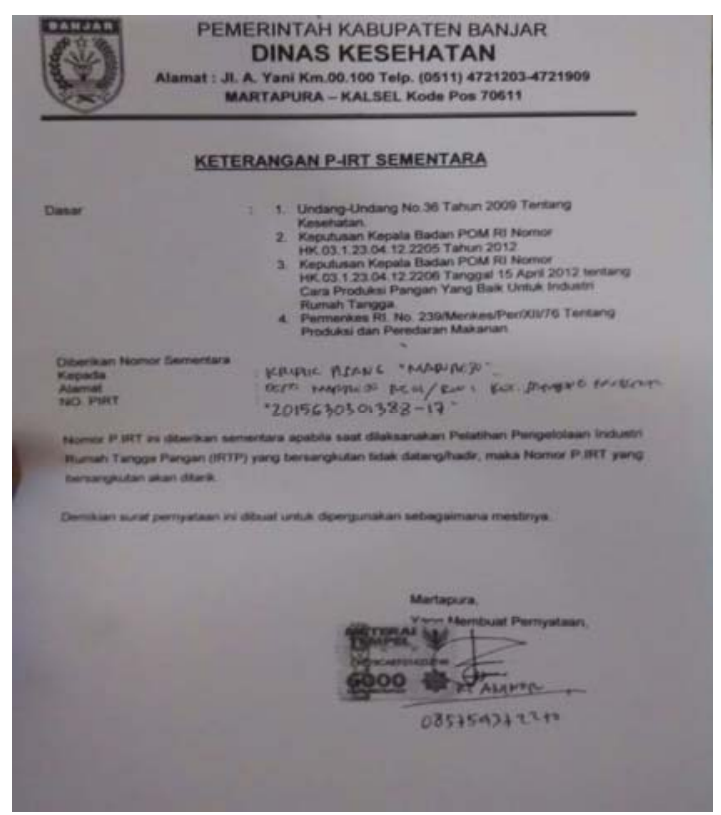

Gambar 14. ljin PIRT

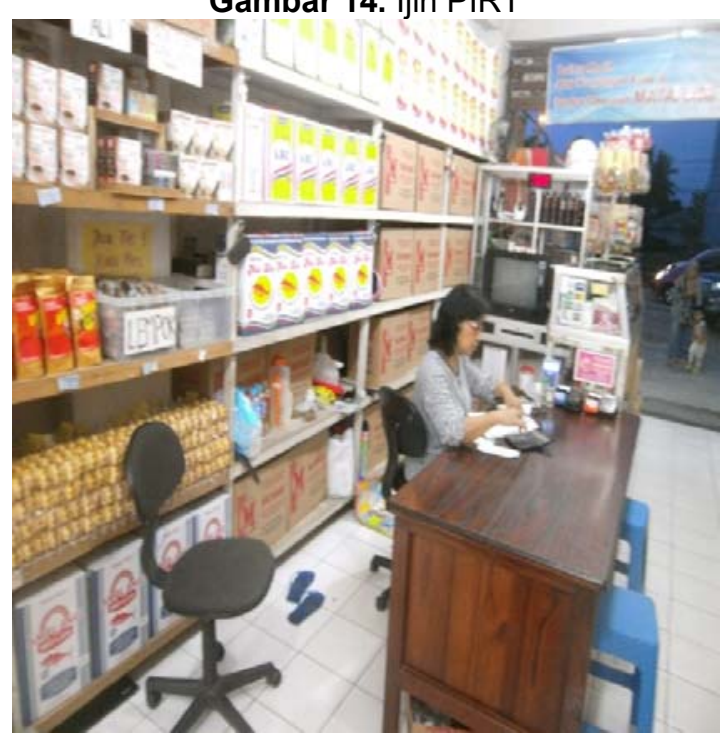

Gambar 15. Toko yang bekerjasama memasarkan Produk KKN

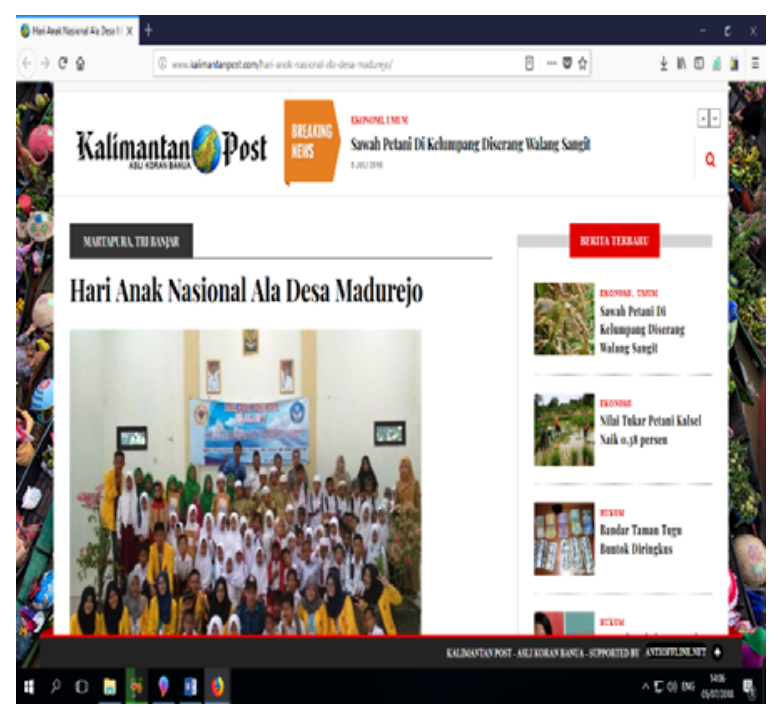

Gambar 16. Publikasi KKN di Harian Kalimantan Post (http://www.kalimantanpost.com/hari-anaknasional-ala-desa-madurejo/)

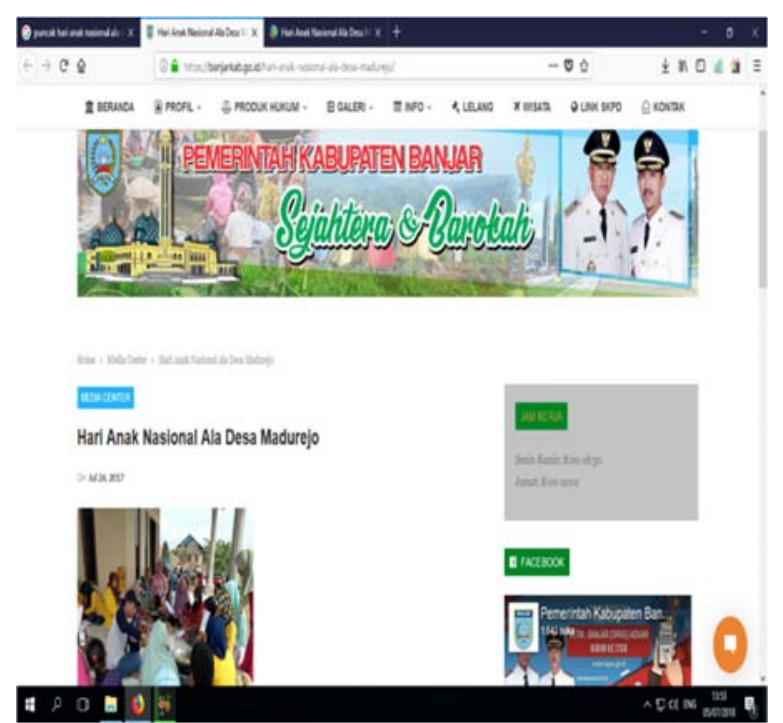

Gambar 17. Publikasi KKN di Website Pemkab Banjar (https://banjarkab.go.id/hari-anak-nasionalala-desa-madurejo/)

\section{SIMPULAN DAN SARAN}

\section{Simpulan}

Dari kegiatan KKN-PPM ini dapat disimpulkan beberapa hal:

a. Terdapat peralatan teknologi tepat guna untuk produksi keripik, Sale, selai dan dodol pisang.

b. Terdapat produk olahan buah pisang berupa Keripik, Sale, Selai dan dodol.

c. Meningkatkan pendapatan masyarakat desa Madurejo dari 1,5 juta menjadi 2 Juta.

d. Terdapat kemasan yang menarik dan ijin usaha atau PIRT 
e. Terdapat jalinan kerjasama dengan minimarket dan toko oleh-oleh

f. Terdapat Publikasi di Koran dan Televisi

g. Meningkatnya Soft Skill Mahasiswa

\section{Saran}

Adapun Saran dari Kegiatan ini adalah:

a. Mitra dapat meningkatkan pendapatan dan meningkat taraf kesejahteraan hidupnya.

b. Produk Mitra semakin dikenal masyarakat.

\section{UCAPAN TERIMA KASIH}

Terima kasih kami sampaikan kepada segala pihak yang telah berkontribusi dalam perencanaan, pelaksanaan, dan pembuatan laporan Akhir pelaksanaan kegiatan. Dalam hal ini kami berterima kasih kepada:

1. Kementerian Riset dan Teknologi atas Hibah yang diberikan

2. Bapak Rektor Universitas Lambung Mangkurat

3. Bapak Ketua LPPM Unlam

4. Bapak Dekan FMIPA Unlam

5. Bapak Camat Sambung Makmur

6. Bapak Pembakal Desa Madurejo

7. Para Pembakal di Kecamatan Sambung Makmur

8. Para Mahasiswa yang telah mengikuti kegiatan KKN

9. Kepada Seluruh Pihak yang telah membantu kegiatan ini

\section{DAFTAR RUJUKAN}

Iqbal. 2015. Harga Buah pisang Tak Mengenal Musim, Banjarmasintime.com.

Putra, Stefanus Dicky Reza, Purwijantiningsih, L.M. Ekawati, \& Pranata, F. Sinung. 2013. Kualitas Minuman Serbuk Instan Kulit Buah Manggis (Garcinia Mangostana Linn.) Dengan Variasi Maltodekstrin Dan Suhu Pemanasan. (Bachelor), Universitas Atma Jaya, Yogyakarta.

Saati, Elfi Anis. 2010. Identifikasi Dan Uji Kualitas Pigmen Kulit Buah pisang Merah (Hylocareus costaricensis) Pada Beberapa Umur Simpan Dengan Perbedaan Jenis Pelarut. GAMMA, 6(1), 25-34.

Wahyuni, Rekna. (2011). Use Super Red Dragon Fruit Skin (Hylocereus costaricensis) As A Source Of Antioxidants In Natural Dyes And Jelly Making. Jurnal Teknologi Pangan, 2(1), 68-85. 